\title{
The Social Policy Vision of Political Parties in Modern Turkey
}

\author{
Günümüz Türkiyesi’ndeki Siyasi Partilerin Sosyal Politika Anlayışı
}

\begin{abstract}
Nuriye ÇELİK *
Abstract: Social policies are the main application area for public policy. It is recognize that there is a wide field of study in the foreign literature about the social policies of developed countries but not in the Turkish literature (Özdemir 2007; Aysan \& Kaya 2008, 224). In this study where we describe the application areas and priority objectives of social policy, we examined the nature of social policy through some specific political approaches such as the conservatives, socialists, liberals and social democrats in Turkey. When we look at all social policy approaches, it seems that the social world is far from the government's intervention in the liberal approach and the socialist approach has created a social world which is state-controlled and without class. The conservative approach is based on development with traditional values together, and the discourses of the social democratic approach, like the liberal and socialist approachs, a critical language is being used and it supports the welfare state and at the same time defends individual freedoms. The reason for the critical language is that the conservative approach is at the same time the ruling party. Therefore, the discourses of other parties have systematic criticism.
\end{abstract}

Keywords: Social Policy, Social State, Political Party Programs

Öz: Sosyal politikalar, kamu politikasının temel uygulama alanıdır. Bu konuda literatüre bakıldığında, geniş bir inceleme alanı olduğu fark edilmektedir. Fakat gelişmiş ülkelerle ilgili olarak bol miktarda yabancı kaynak bulunabilirken, Türkiye'de refah devleti konusu hakkında geniş bir yayın kaynağı bulunmamaktadır (Özdemir 2007; Aysan \& Kaya 2008, 224). Sosyal politikanın uygulama alanlarının ve hedeflerinin tanımlandığı bu çalışmada, sosyal politikanın günümüzdeki doğası Türkiye'deki muhafazakar, sosyalist, liberal ve sosyal demokrat politika yaklaşımları vasıtasıyla incelenmiştir. Tüm sosyal politika yaklaşımlara bakıldığında, liberal yaklaşımın devletin müdahalesinden uzak bir sosyal dünya; sosyalist yaklaşımın sınıfsız, kamunun ağırlığının hissedildiği bir sosyal dünya yarattığı görülmektedir. Muhafazakâr yaklaşım ilerlemeyi geleneksel değerlerine bağlı olarak hedeflerken, sosyal demokrat yaklaşımın söyleminde, liberal ve sosyalist yaklaşımda olduğu gibi, eleştirel bir dil kullanılmakta olup, sosyal devleti destekleyen ve aynı zamanda bireysel özgürlükleri de korumaya çalışan bir yaklaşım görülmüştür. Bu durumun nedeni muhafazakâr yaklaşımın aynı zamanda iktidar partisi olmasıdır. Dolayısıyla diğer partilerin söylemleri sistem eleştirisi nitelikleri taşımaktadır

Anahtar sözcükler: Sosyal Politika, Sosyal Devlet, Siyasi Parti Programları

\section{Introduction}

The word policy derives from the Greek polis (a word meaning city), and it was used in the related period in the sense of state affairs. In general, policy is a struggle and effort to provide integration in the society, with very general interests rather than private interests and to realize the good of society (Öztekin 2003). The concept of social policy was first introduced by

\footnotetext{
* Doktora Öğrencisi, Selçuk Üniversitesi, Sosyoloji Anabilim Dalı, Selçuk. nuriyesenelcelik@gmail.com
} 
Wilhelm Heinrich Riehl in the nineteenth century. The concept of social policy began to be discussed with the establishment of the association named Verein für Sozialpolitik in 1873, in which liberal and socialist considerations were discussed in Germany (Aysan \& Kaya 2008, 225). Social policy can be defined as an area where the state fulfills its responsibilities and duties to its citizens. Apart from the mechanisms for increasing human resources such as health, education and other social, cultural and economic infrastructures and social security, welfare programs for combating poverty and social isolation have played an important role in many countries in recent years in the field of social policy. However, the social policy area does not only satisfy the specific needs of citizens; at the same time, it functions as a collective of practices that regulate state relations with citizens and thus it is associated with concepts such as citizenship, the state, the community, and the people. The social state is a state, which is obliged to protect the powerless in society against various forces and to ensure real equality, namely the state is to provide social justice and social balance. Public policy can be defined as the methods of action that the state chooses to do or not to do, from a broad perspective. This definition is crucial in terms of understanding that the way of government's actions, not only positive actions and laws, but also as a public policy, chose not to do anything about some issues. Social policy is the most debated issue in terms of both concept and content. The concept of "social policy" in Europe and "social welfare policy" in North America has been used (Özdemir 2007, 12). There is a view that explains the beginning of social policy as industrialization and its content is the problems of the working class emerging with industrialization and solutions to that problem, which are applied by the state. The concept of the social state was first used by Archbishop Temple in England in the same sense as the welfare state. But the concept of the welfare state began to be used for economic development with the establishment of the social insurance system in 1883 in Germany by Bismarck (Ören 2013, 6).

However, the state is not alone in the implementation of social policies. Other institutions function in the direction of reducing the need for the state. According to this point of view; for a person in a poor situation, he or she has to first strive for himself, then seek the help of his neighbours and/or relatives, and then be supported by social institutions such as religion or charity and after a person has passed through all these stages, if he/she is still unable to reach the needed living conditions, then he/she should apply to the state (Ersöz 2011, 120). In addition, social policies are being carried out not only in the concerned states, but also through international organizations, and the most basic example in this regard is the European Union. Subsequently, organizations such as the World Health Organization, the IMF, and UNICEF will be striking. Social policies have progressed parallel to the development and progress of social rights. Social rights includes rights granted by the state and requested by the individual to attain minimum human living conditions. Negative rights that an individual has to demand and which should not be interfered with by others while using it; positive rights are those rights that need others help while using. The negative life right prevents a person from being killed by others and the positive life right requires helping the person who will be killed if not helped. Examples of negative rights are political rights such as freedom of speech, property, and freedom of belief; and examples of positive rights are education and social security.

In this study, the party programs of the political parties were taken into consideration from all political approachs which produces social policies. The matter of the education policy, the health policy, social security politics, women politics, youth and sports politics, family and social services politics, cultural politics and science politics were selected, through the fourparty programs examined, and the data obtained from this analysis is classified and compared. Under every social policy topic, some important issues are listed and these issues are selected 
according to the related social policy topic: for example, under women politics, motherhood at work and women rights issues are examined.

\section{Development of Social Policy}

In the broad sense, the Social policy is a humanistic science that aims to provide social justice and social welfare, while providing social qualities to economic science and producing corrective policies; in a narrow sense, is the whole of the practices against social problems such as unemployment and poverty prevention which emerging after the industrial revolution (Oral et al. 2012, 5). For this reason, changes in the economic structure and social-political preferences of states have been influential in the developmental process of social policy. We can divide the development process of social policy into five economic terms: post-antiquity (pre-1880), industrialization (1880-1914), between the two world wars (1914-1945), post-World War II (1945-1975), the term changing from welfare policy to the neoliberal perspective (after 1975) (Özdemir 2007). The changing economic approaches have also affected and transformed the content of social policy. In addition, the understanding of social policy can be interpreted in a variety of ways, through neoliberalism, conservatism, social democracy, socialist perspective, third way, feminist approach, green approach and postmodern perspectives (Alcock et al. 2008, 87-108). Accordingly, the understanding of social policy of each approach has certain differences. While neo-liberal ideas aim to reduce public spending, conservative tradition advocates equitable access to services in social policy which is produced by a central government.

The concept of social politics began with a humanist and benevolent vision and it has been discussed more frequently since World War II (Ersöz 2011, 121). The first international social policy research began with Robert Owen (1830-1840) in England, Daniel Le Grand (18401855) in France, but the first formal study was done in Switzerland in 1881 (Oral et al. 2012, 21). However, the actual studies took placed after World War II because of the conditions of the period. The history of social policy extends from the "Poverty Laws" which began in the 1300's and continued in the 1800's in England for people living in difficult condition due to the feudal structure, wars and shortages, through the Middle Ages with support for the poorest families from guilds (Özdemir 2005, 241). These laws, which were applied in the UK and in the American colonies are important, in regard to finding work for the poor who can work and to put in prison those who reject work and that those who cannot work should be looked after in institutions called "alms-house" with young children being directed into apprenticeships or domestic work (Ersoz 2011, 122-3).

The first need for social policy emerged in the factorization term while agricultural production became serial production, after the industrial revolution. Social policy requests were born after worker accidents, malnutrition, and bad working conditions and worthless of labour, a redundant industrial army, child workers, long working hours, women workers working in heavy, night shifts, and the results of increased migration. Because of the contribution of "Protestant Morality," working hard was blessed and poverty seemed the results of individuals' actions and in the same period the "Darwinian Approach" offered the survival of the fittest and the destruction of the lost in the war (Ersöz 2011, 125). The state intervention required by the current structure emerged during the development period of industrialization, the $19^{\text {th }}$ century and after the 1920's, the concept of the social policy was adopted to a descriptive structure instead of the prohibitive way. The aim of Britain, Canada, America, Germany, and France (the capitalist countries of the period) became to accept social policies such as: income support, education, and social aid. The Great Depression of 1929 expanded the reach of social policy and 
the liberal policies that were criticized because of the crisis, were abandoned and the Keynesian approach was adopted. In developed countries, the period up to the 1970's is considered the golden period/the welfare years, and social policy was the primary duty of the state. In this period, the state became the sole owner of many fields such as education, health, transportation, and production.

The process that began with the demand for social rights and pushed the state to prevent social explosions by producing social policies; was not easy and it faced great challenges. For example, the first challenges to working hours began in the $14^{\text {th }}$ century and it was not in today's sense, but in the form of demanding the right not to work only on religious festivals and on special occasions. However, the demands of the working days like those of the present were obtained in the $18^{\text {th }}$ century in the UK through the calculation of the daily labour fee. But the circumstances are shaped, of course, according to demands of capitalism: working 13-14 hours a day, 7 days a week, without discrimination between women and children, and the material and spiritual misery of the proletariat (Oral et al. 2012, 86 from İnsel 2011). These conditions created conscience of the chaos in the society and people wanted to stand against this misery in front of their eyes. These thoughts brought the state to create social policy. In 1884, trade unions in the United States first demanded that their daily working hours have to be reduced to 8 hours, and that day became very important as May 1 . In the $19^{\text {th }}$ century, a day's weekly vacation was obtained in some businesses. In the $20^{\text {th }}$ century annual working hours fell below 2000; but in subsequent years, neoliberal understanding slowed down this kind of social policy practice (Oral et al. 2012, 86 from İnsel 2011).

By the end of the 1970's, public debt, which increased with the first and second oil shocks, budget deficits, and inflation found the state guilty. Both the Marxists and the neoliberals blamed the state for intervening in the economy and the social system experienced further problems such as the increasing number of unemployed, an ageing population, increasing divorces. The Keynesian policies were seen to have failed. In this environment accusing the state, institutions such as active citizenship, voluntary service execution, private retirement and the demand of decreasing the share of the state in social life emerged; some social institutions such as religion, family, voluntary organizations begun to work at the field that formerly was the duty of the state. In the last period, with the influence of globalization, state interventions generally have been an unwanted policy and social policies has become an area where there is always discussion as to who should be helped and at what level, and will these policies harm the economic system. From an overall point of view it can be seen that the evolution of social policy applications has been affected by liberal thought, by socialist thought, by a welfare state, and by neo-liberalism (Özdemir 2007).

\section{Tools of Social Policy}

The French Revolution and the Industrial Revolution were not enough for individuals to live in peace and justice; the economic process has created people in misery; while capitalism increases its profit with low wage labour, it has also created uneasiness and an atmosphere of delirium among the workers. The disorganized distribution of income has caused the social crisis because of the direct relations of the lower and upper institutions. The social policies that states have produced in order to stop this trend, has taken legal, institutional and political regulations as instruments to restore social well-being, to distribute equality of income and to provide each individual with decent living conditions. In this context, the national instruments used by states in applying social policy (Oral et al. 2012, 17-20) are public intervention, legislation, public policies, institutions, unions which is self-sufficiency but, at the same time, in business alliance 
with the state, foundations, and associations. International institutions and organizations have emerged because of the understanding that nation states are not sufficient and that universal acceptance is necessary for the practice of applying of social policy. In this sense, there are the international instruments the International Labour Organization (ILO), the United Nations (UN), the European Union (EU), the Economic Cooperation and Development Organization (OECD), the World Health Organization (WHO), the United Nations Food and Agriculture Organization (FAO) , The World Trade Union Confederation (WFTU), the International Confederation of Free Trade Unions (ICFTU), the Third Way, the Greens and the Feminist Movements (Oral et al. 2012, 20-3). At the emergence, development, and implementation of social policy, there are some texts such as the Magna Carta, the American Declaration of Independence, the Universal Declaration of Human Rights, etc., in which peoples declared their demands for human living conditions. According to the Declaration of Philadelphia (The Declaration of Philadelphia is a statement of aims adopted by the International Labour Organization in 1944 and embodies basic principles of economic justice. It declared the following: that labour is not a commodity; that freedom of expression and of association are essential to progress; that poverty anywhere constitutes a danger to prosperity everywhere; and that all human beings, irrespective of race, creed, or sex, have the right to pursue both their material well-being and their spiritual development in conditions of freedom and dignity, of economic security, and equal opportunity. The Declaration continues to provide a focus for campaigners for international labour standards (http://oxfordindex.oup.com/view/10.1093/oi/authority.20110803095705910)):

\footnotetext{
"Labour is not a commodity. Freedom of expression and of association are essential to sustained progress. Poverty anywhere constitutes a danger to prosperity everywhere. The war against want requires ... unrelenting vigor... (for) the promotion of the common welfare. All human beings, irrespective of race, creed or sex, have the right to pursue both their material well-being and their spiritual development in conditions of freedom and dignity, of economic security and equal opportunity" (https://en.wikipedia.org/wiki/Declaration_of_Philadelphia).
}

As can be seen from their inscriptions, the application of social policy is considered as a right, and individuals have the right to demand that policies meet these aims.

\section{Classification of Social Policy in Turkey}

In a country, the state aims to achieve the happiness and well-being of the people of the country and applies the social policy, which the decisions are taken by the state for health, education, security, nutrition, protection, shelter and employment of citizens. Therefore, all kind of social policies are classified by the state according to these practices. In the Constitution of the Republic of Turkey's (https://www.tbmm.gov.tr/anayasa/anayasa82.htm) fundamental rights and duties section, under the third part, with the title the Social and Economic Rights and Duties, these fields have named social policies:

- Protection of the family;

- The right to education

- Freedom of labour and contract,

- The right to collective bargaining, the right to strike and lock-out, the provision of justice in wages;

- Health, environment, and housing;

- Youth and sports;

- Social security rights; 
- Protection of history, culture and natural assets.

- In that sense, the origin of the application areas of social policies is based upon the Republic of Turkey's constitution.

\section{The Sense of Social Policy in Turkey}

The development of social policy in Turkey has been spread over a process that began under the Ottoman Empire. During the Ottoman period, there was a social life provided by the religious and social structure. In crowded families, a social understanding was developed in which the elderly person is respected due to the Islamic religion, and the poor were supported through religious foundations (Vakif) and by worshippers through almsgiving and charity. However, there were no social policy institutions at the state level and these practices were voluntary. "These aids, which are made with human feelings such as pity, compassion, or religious feelings, leave individuals at the mercy of other individuals, and imbalance can occur in the distribution of resources. Because they do not have an institutional framework for how, when, and to whom, they cannot be assessed as a modern social policy measure” (Şişman 2017, 3). Apart from this aid, based upon religion and voluntary work, the organized structures established in business life such as foundations and guilds and the financial support of the rich were obtained. The Ahi Community (Akhism, an organized brotherhood in Anatolia related to the trade guilds), which were affected up to the fifteenth century, supported ethics in business and honesty in business life. After the Reorganization Period in 1839, through westernization efforts, the commercial social policy applications by Empire, were seen for the first time and the process of business life became written into law (Şişman 2017, 5). The Eregli Coal Mine Public Administration Regulations for worker's rights in 1865, Kizılay with the name of the Ottoman Legal Military Aid Society in 1868, Darülaceze (almshouse) for those living in the streets, Darüşşafaka (charity house for children's care and education) for the education of the children who have no father and have no financial resources, were opened in this period.

In the economic struggle that began with the declaration of the Republic, the Congress of Economics (17 February-4 March 1923), which collected in Izmir was a great benchmark. In this Congress, the correction of adverse working conditions; the recognition of the right to syndication; limiting of the daily working time to 8 hours; the lowest level of wages is determined in city councils every 3 months, 12 years of age for the industry sector as the minimum age of employment and 18 for the mining sector; and social security was expressed (Şişman 2017, 7). The first labour law in Turkey was adopted in June 1936. The Populism ideology (this ideology refers to political activities or ideas that claim to promote the interests and opinions of ordinary people) of the CHP (Republican People's Party) that was the only party during the period from 1936-1945, required producing social policies. In this respect the Village Institutes were opened and the intention was to train teachers for village schools, and, therefore, it was desirable to avoid the inequality of opportunities and the center-periphery distinction in the education system.

1946-1960 was a period in which policies that were more liberal were adopted. For this reason, in this period statist politics were under the influence of liberal policies and the result was a mixed economy. The introduction of the Truman Doctrine and the Marshall Plan, which was declared by the United States in 1947, restricted the state's territory. Between 1960 and 1980, the social character of the state was emphasized, and through a reform in some laws of the Constitution, the freedom of unionization and social movements was recognized. In the political process that began with the 1982 Constitution, "the state has moved away from own social character; the subjects of the global economy and neo-liberal policies such as budget deficits, 
the stock market, and the ups and downs of interest have occupied the agenda and have developed a state understanding limited to justice, security and foreign policy issues" (Şişman 2017, 15). Problems in the social structure have required the establishment of the Social Services and Child Protection Agency in 1983, and the Social Assistance and Solidarity Encouragement Fund in 1986. Today, social policy understanding that changes depending on the economic and social structure, is shaped by the political opinion of the political authority.

According to Buğra, "until the 1980s, when an outward-looking and market-oriented development strategy was adopted, the social-policy outlook in republican Turkey manifested certain differences from the one characterizing the history of modern capitalist development in Europe" (Buğra 2007, 33). Because of any kind of political and economic changes, the social policy approach was also regulated. According to Boratav:

"Since its early inception, Turkish adjustment the program was hailed as a model by the orthodox international community and supported by generous structural adjustment loans, debt relief, and technical aid. Currently (in 2000), the Turkish economy can be said to be operating under conditions of a truly open economy a macroeconomic environment where both current and capital accounts are completely liberalized" (Boratav et al. 2000, 2).

In Turkey, there is a government, the practitioners of social policies and there are political parties which produce alternative social policies to those of the government. While it is not meant that these political parties are separated by sharp boundaries, it is possible to distinguish between conservative, liberal, socialist and social democratic by separating them from their general political attitudes. AK Party, (http://www.akparti.org.tr/site) the most important representative power of conservative opinion in the country, is the practitioner, and producer of important political policies with 16 years of political power. The Liberal Democratic Party (http://www.ldp.org/) is the only political institution in the country that defends the liberal view both politically and economically. The Communist Party of Turkey (http://www.tkp.org.tr/) has a claim to organize the working class, which is the leading power of the Turkish socialist revolution, and lead the revolution and with this opinion it has a significant difference from the similar left-wing political party. The Republican People’s Party (https://www.chp.org.tr/) which was founded by Mustafa Kemal Atatürk on September 9, 1923, as the continuation of the Association for the Defence of the Rights of Anatolia and Rumelia, and today it is in political life as a centre-left and the main opposition party. In order to compare the political approaches that generate social policy, the party programs of some political parties have been taken into account through representing the relevant political views.

\section{Research Problem}

This study aims to present an overview of four different political approaches in Turkey's modern political life to social policy. In doing so, social policy implementations are not included. Because political views which have never had political power, cannot apply any social policy. Therefore, the evaluation between political views has been carried out through the content analysis of the political party programs.

\subsection{Objectives and Method}

In this study, the social policy views of conservatives, socialist, liberal and social democrat approaches were tabulated by evaluating the current versions in May 2018 of the party programs of the four political parties representing these views. As there may be changes in the approach 
of political parties in the historical process, this study has been careful to evaluate the current status of these party programs. Expressions related to the headings used in the classification of social policy were obtained from the party programs.

\subsection{Data Analysis and Findings}

In order to compare the political approaches that generate social policy, the party programs of some political parties have been taken into account to represent the relevant political views. Through the four-party programs examined, common topics such as education policies, health policies, social security policies, women politics, youth and sports politics, family and social services politics, cultural politics and science politics were selected and, under these topics, through some issues, the approaches have been examined. The data, which was obtained from this analysis, is tabulated as follows:

Table 1. Social Political Approaches in Education Politics

\begin{tabular}{|c|c|c|c|c|c|c|c|c|c|c|c|c|}
\hline & \multicolumn{2}{|c|}{$\begin{array}{l}\text { Basic } \\
\text { education has } \\
\text { to be } \\
\text { compulsory. }\end{array}$} & \multicolumn{2}{|c|}{$\begin{array}{l}\text { The term of } \\
\text { compulsory } \\
\text { education in } \\
\text { basic } \\
\text { education } \\
\text { should be } \\
\text { increased. }\end{array}$} & \multicolumn{2}{|c|}{$\begin{array}{l}\text { Education } \\
\text { should be } \\
\text { completely } \\
\text { free. }\end{array}$} & \multicolumn{2}{|c|}{$\begin{array}{l}\text { Private } \\
\text { education } \\
\text { schools should } \\
\text { be supported. }\end{array}$} & \multicolumn{2}{|c|}{$\begin{array}{l}\text { During the } \\
\text { education } \\
\text { process, } \\
\text { technology } \\
\text { should provide } \\
\text { maximum benefit } \\
\text { to this process. }\end{array}$} & \multicolumn{2}{|c|}{$\begin{array}{l}\text { The most } \\
\text { fundamental } \\
\text { problem in } \\
\text { education is } \\
\text { inequality of } \\
\text { opportunity. }\end{array}$} \\
\hline & Yes & No & Yes & No & Yes & No & Yes & No & Yes & No & Yes & No \\
\hline $\begin{array}{l}\text { Conservative } \\
\text { approach }\end{array}$ & $\checkmark$ & & $\checkmark$ & & $\checkmark$ & & $\checkmark$ & & $\checkmark$ & & $\checkmark$ & \\
\hline Liberal approach & $\checkmark$ & & & $\checkmark$ & & $\checkmark$ & $\checkmark$ & & $\checkmark$ & & & $\checkmark$ \\
\hline $\begin{array}{l}\text { Socialist } \\
\text { approach }\end{array}$ & $\checkmark$ & & $\checkmark$ & & & & & $\checkmark$ & $\checkmark$ & & $\checkmark$ & \\
\hline $\begin{array}{l}\text { Social democratic } \\
\text { approach }\end{array}$ & $\checkmark$ & & $\checkmark$ & & & & $\checkmark$ & & $\checkmark$ & & $\checkmark$ & \\
\hline
\end{tabular}

According to the liberal view, the most fundamental problem in the education system is the authority of the state and the obligation of the curriculum in the system, whereas in the conservative view, besides that the inequality of opportunity in education and the complexity of the system, another important problem is that system is the arena of political conflict. The social democratic approach emphasizes that educational policies should be free from political influence.

Table 2. Social Political Approaches in Health Politics

\begin{tabular}{|c|c|c|c|c|c|c|c|c|c|c|}
\hline & \multicolumn{2}{|c|}{$\begin{array}{l}\text { Basic health } \\
\text { expenditure } \\
\text { should be free. }\end{array}$} & \multicolumn{2}{|c|}{$\begin{array}{l}\text { The whole system } \\
\text { should be managed } \\
\text { from a single centre } \\
\text { (Ministry of } \\
\text { Health). }\end{array}$} & \multicolumn{2}{|c|}{$\begin{array}{l}\text { Private } \\
\text { healthcare } \\
\text { institutions } \\
\text { should be } \\
\text { encouraged. }\end{array}$} & \multicolumn{2}{|c|}{$\begin{array}{l}\text { Support funds should } \\
\text { be established for } \\
\text { scientific research in } \\
\text { the medical field. }\end{array}$} & \multicolumn{2}{|c|}{$\begin{array}{l}\text { The health system } \\
\text { includes every citizen } \\
\text { regardless of his or } \\
\text { her income level. }\end{array}$} \\
\hline & Yes & No & Yes & No & Yes & No & Yes & No & Yes & No \\
\hline $\begin{array}{l}\text { Conservative } \\
\text { approach }\end{array}$ & & $\checkmark$ & $\checkmark$ & & $\checkmark$ & & $\checkmark$ & & $\checkmark$ & \\
\hline $\begin{array}{l}\text { Liberal } \\
\text { approach }\end{array}$ & & $\checkmark$ & & $\checkmark$ & $\checkmark$ & & & $\checkmark$ & & $\checkmark$ \\
\hline $\begin{array}{l}\text { Socialist } \\
\text { approach }\end{array}$ & $\checkmark$ & & $\checkmark$ & & & $\checkmark$ & - & & $\checkmark$ & \\
\hline $\begin{array}{l}\text { Social } \\
\text { democratic } \\
\text { approach }\end{array}$ & & $\checkmark$ & & $\checkmark$ & $\checkmark$ & & $\checkmark$ & & $\checkmark$ & \\
\hline
\end{tabular}


As regards basic health expenditures, the social democratic approach argues there should not be taken an additional fee from citizens who do not have financial power, under the name of contribution. Again, according to the Social Democratic approach, the National Health Insurance Agency must finance the health service provided to citizens and must be competent and in charge of inspecting all the details of the process of health service. As the approach of the communists, it is accepted among the duties of the government to follow scientific developments; because the entire health system should in the hands of the state.

Table 3. Social Political Approaches in Social Security Politics

\begin{tabular}{|c|c|c|c|c|c|c|c|c|c|c|}
\hline & \multicolumn{2}{|c|}{$\begin{array}{l}\text { The social } \\
\text { security } \\
\text { system has to } \\
\text { be completely } \\
\text { unprofitable }\end{array}$} & \multicolumn{2}{|c|}{$\begin{array}{l}\text { The social security } \\
\text { system includes } \\
\text { every citizen } \\
\text { regardless of his or } \\
\text { her income level. }\end{array}$} & \multicolumn{2}{|c|}{$\begin{array}{l}\text { Private health } \\
\text { and life } \\
\text { insurance } \\
\text { companies } \\
\text { should be } \\
\text { encouraged. }\end{array}$} & \multicolumn{2}{|c|}{$\begin{array}{l}\text { The elderly people } \\
\text { who need care } \\
\text { should be looked } \\
\text { after in the family } \\
\text { and this is } \\
\text { encouraged by the } \\
\text { state. }\end{array}$} & \multicolumn{2}{|c|}{$\begin{array}{l}\text { Social aid } \\
\text { should be } \\
\text { provided to } \\
\text { people who are } \\
\text { elderly and need } \\
\text { care. }\end{array}$} \\
\hline & Yes & No & Yes & No & Yes & No & Yes & No & Yes & No \\
\hline Conservative approach & & $\checkmark$ & $\checkmark$ & & $\checkmark$ & & $\checkmark$ & & $\checkmark$ & \\
\hline Liberal approach & & $\checkmark$ & & $\checkmark$ & $\checkmark$ & & & - & & $\checkmark$ \\
\hline Socialist approach & $\checkmark$ & & $\checkmark$ & & & $\checkmark$ & & - & $\checkmark$ & \\
\hline $\begin{array}{ll}\begin{array}{l}\text { Social } \\
\text { approach }\end{array} & \text { democratic } \\
\end{array}$ & & $\checkmark$ & $\checkmark$ & & $\checkmark$ & & & - & $\checkmark$ & \\
\hline
\end{tabular}

The idea of supporting the care of the elderly person who needs care is produced from the concept protecting the family in the conservative approach and the other approaches do not have an idea and priority like that. However, when considering all approaches, it is thought that the other approaches will not support such a social policy application.

Table 4. Social Political Approaches in Woman Politics

\begin{tabular}{|c|c|c|c|c|c|c|c|c|c|c|}
\hline & \multicolumn{2}{|c|}{$\begin{array}{l}\text { Women should } \\
\text { be positively } \\
\text { discriminated in } \\
\text { business life. }\end{array}$} & \multicolumn{2}{|c|}{$\begin{array}{l}\text { The number of } \\
\text { female employees } \\
\text { should be } \\
\text { encouraged, and } \\
\text { supported with a tax } \\
\text { exemption et al. }\end{array}$} & \multicolumn{2}{|c|}{$\begin{array}{l}\text { Kindergarten and } \\
\text { breastfeeding } \\
\text { rooms should be } \\
\text { encouraged in the } \\
\text { workplace. }\end{array}$} & \multicolumn{2}{|c|}{$\begin{array}{l}\text { The social rights of } \\
\text { women, who are } \\
\text { working in the home } \\
\text { have to be ensured } \\
\text { and included in the } \\
\text { social security } \\
\text { system. }\end{array}$} & \multicolumn{2}{|c|}{$\begin{array}{l}\text { Women's } \\
\text { participation in } \\
\text { political and } \\
\text { public life } \\
\text { should be } \\
\text { encouraged. }\end{array}$} \\
\hline & Yes & No & Yes & No & Yes & No & Yes & No & & \\
\hline $\begin{array}{l}\text { Conservative } \\
\text { approach }\end{array}$ & & $\checkmark$ & & $\checkmark$ & & $\checkmark$ & $\checkmark$ & & $\checkmark$ & \\
\hline $\begin{array}{l}\text { Liberal } \\
\text { approach }\end{array}$ & & $\checkmark$ & & $\checkmark$ & & $\checkmark$ & & $\checkmark$ & $\checkmark$ & \\
\hline $\begin{array}{l}\text { Socialist } \\
\text { approach }\end{array}$ & $\checkmark$ & & $\checkmark$ & & $\checkmark$ & & $\checkmark$ & & $\checkmark$ & \\
\hline $\begin{array}{l}\text { Social } \\
\text { democratic } \\
\text { approach }\end{array}$ & $\checkmark$ & & $\checkmark$ & & $\checkmark$ & & $\checkmark$ & & $\checkmark$ & \\
\hline
\end{tabular}


It seems that the conservative approach has supported the woman's family life and protected her motherhood and responsibilities, such as household chores, which based upon the protection of the family. In the socialist approach, dominant opinion is that "The obligations which are given by the capitalist society, of women such as cooking, cleaning, childcare et al. should be taken over and shared by the whole society using collective possibilities". As the intervention in the business sector is a failure according to the liberal approach, incentives such as discrimination on behalf of women or tax exemption are not accepted. There are ideologically relatively sharp boundaries concerning the social position of women. In addition, it is to be observed there is a similarity between liberals and conservatives and a similarity between socialists and social democrats about this issue, different from the other headings.

Table 5. Social Political Approaches in Young and Sport Politics

\begin{tabular}{|c|c|c|c|c|c|c|c|c|}
\hline & \multicolumn{2}{|c|}{$\begin{array}{l}\text { It should be } \\
\text { ensured that } \\
\text { young people } \\
\text { take an interest } \\
\text { in sports. }\end{array}$} & \multicolumn{2}{|c|}{$\begin{array}{l}\text { Political } \\
\text { participation of } \\
\text { young people } \\
\text { should be } \\
\text { increased. }\end{array}$} & \multicolumn{2}{|c|}{$\begin{array}{l}\text { Great importance } \\
\text { should be attached to } \\
\text { young people in rural } \\
\text { and poor areas. }\end{array}$} & \multicolumn{2}{|c|}{$\begin{array}{l}\text { A youth and generation, } \\
\text { which is a creative, free } \\
\text { and respectful of human } \\
\text { rights should be created. }\end{array}$} \\
\hline & Yes & No & Yes & No & Yes & No & Yes & No \\
\hline Conservative approach & $\checkmark$ & & $\checkmark$ & & $\checkmark$ & & $\checkmark$ & \\
\hline Liberal approach & $\checkmark$ & & $\checkmark$ & & & $\checkmark$ & $\checkmark$ & \\
\hline Socialist approach & $\checkmark$ & & $\checkmark$ & & $\checkmark$ & & $\checkmark$ & \\
\hline Social democratic approach & $\checkmark$ & & $\checkmark$ & & $\checkmark$ & & $\checkmark$ & \\
\hline
\end{tabular}

Although a common approach has been observed in youth policies, the conservative approach requires that youth should build the social structure, which is aware of their identity of religion with national values. While the social democratic approach demands a secular and free thought from youth; in the socialist approach it is forbidden to work under the age of 18 and it demands a classless and propertyless society from them.

Table 6. Social Political Approaches in Family and Social Services Politics

\begin{tabular}{|c|c|c|c|c|c|c|c|c|}
\hline & \multicolumn{2}{|c|}{$\begin{array}{l}\text { Violence } \\
\text { within a } \\
\text { family should } \\
\text { be prevented. }\end{array}$} & \multicolumn{2}{|c|}{$\begin{array}{l}\text { Family life has } \\
\text { to be preserved. }\end{array}$} & \multicolumn{2}{|c|}{$\begin{array}{l}\text { It should be ensured } \\
\text { families have their } \\
\text { own house with long- } \\
\text { term housing loans. }\end{array}$} & \multicolumn{2}{|c|}{$\begin{array}{l}\text { Poor families should be } \\
\text { supported and education of } \\
\text { their children has to be } \\
\text { provided by the state. }\end{array}$} \\
\hline & Yes & No & Yes & No & Yes & No & Yes & No \\
\hline Conservative approach & $\checkmark$ & & $\checkmark$ & & $\checkmark$ & & $\checkmark$ & \\
\hline Liberal approach & $\checkmark$ & & $\checkmark$ & & & $\checkmark$ & & $\checkmark$ \\
\hline Socialist approach & $\checkmark$ & & $\checkmark$ & & $\checkmark$ & & $\checkmark$ & \\
\hline Social democratic approach & $\checkmark$ & & $\checkmark$ & & $\checkmark$ & & $\checkmark$ & \\
\hline
\end{tabular}

The violence within a family is the primary problem in family related social policies. After that, a common opinion is expressed in the direction of the protection of the family. According to the socialist approach, "the family must abandon the economic and ideological role that capitalism imposes on it" and turn into the shape which the loves the fundamental. 
Table 7. Social Political Approaches in Culture Politics

\begin{tabular}{|c|c|c|c|c|c|c|c|c|}
\hline & \multicolumn{2}{|c|}{$\begin{array}{l}\text { National and domestic } \\
\text { values should be } \\
\text { protected and } \\
\text { improved primarily. } \\
\end{array}$} & \multicolumn{2}{|c|}{$\begin{array}{l}\text { Domestic and foreign } \\
\text { media and cultural } \\
\text { activities should be } \\
\text { supported. }\end{array}$} & \multicolumn{2}{|c|}{$\begin{array}{l}\text { Individual cultural } \\
\text { values should be } \\
\text { protected and supported } \\
\text { by common values. } \\
\end{array}$} & \multicolumn{2}{|c|}{$\begin{array}{l}\text { State control and } \\
\text { supervision in the } \\
\text { performing arts should } \\
\text { not be allowed. }\end{array}$} \\
\hline & Yes & No & Yes & No & Yes & No & Yes & No \\
\hline $\begin{array}{l}\text { Conservative } \\
\text { approach }\end{array}$ & $\checkmark$ & & & $\checkmark$ & & $\checkmark$ & & $\checkmark$ \\
\hline Liberal approach & & $\checkmark$ & $\checkmark$ & & $\checkmark$ & & $\checkmark$ & \\
\hline $\begin{array}{l}\text { Socialist } \\
\text { approach }\end{array}$ & & $\checkmark$ & $\checkmark$ & & $\checkmark$ & & & $\checkmark$ \\
\hline \begin{tabular}{|l} 
Social \\
democratic \\
approach
\end{tabular} & $\checkmark$ & & & $\checkmark$ & $\checkmark$ & & $\checkmark$ & \\
\hline
\end{tabular}

While native and national cultural values and Turkish-Islamic arts are emphasized in the conservative approach, the liberal approach rejects the presence of the state in the cultural sphere. The socialist approach criticizes the commodification of cultural elements and advocates the expropriation of them and the opening to the public. The liberal approach demands the promotion of foreign media by emphasizing the universal nature of the culture.

Figure 8. Social Political Approaches in Science Politics

\begin{tabular}{|l|c|c|c|c|c|c|c|c|}
\hline & \multicolumn{2}{|l|}{$\begin{array}{l}\text { The share of research } \\
\text { and development } \\
\text { expenditure in the } \\
\text { budget should be } \\
\text { increased. }\end{array}$} & $\begin{array}{l}\text { Scientists should be } \\
\text { supported by the state, } \\
\text { especially in } \\
\text { international projects. }\end{array}$ & $\begin{array}{l}\text { The state should } \\
\text { endeavor to } \\
\text { reverse brain } \\
\text { migration. }\end{array}$ & $\begin{array}{l}\text { The Science } \\
\text { authorities should } \\
\text { work independently } \\
\text { from the state. }\end{array}$ \\
\hline & Yes & No & Yes & No & Yes & No & Yes & No \\
\hline Conservative approach & $\checkmark$ & & $\checkmark$ & & $\checkmark$ & & & $\checkmark$ \\
\hline Liberal approach & & $\checkmark$ & & $\checkmark$ & & $\checkmark$ & $\checkmark$ & \\
\hline Socialist approach & $\checkmark$ & & $\checkmark$ & & & $\checkmark$ & & $\checkmark$ \\
\hline Social democratic approach & $\checkmark$ & & $\checkmark$ & & $\checkmark$ & & $\checkmark$ & \\
\hline
\end{tabular}

According to the liberal approach, the state should not have a science policy and not have a cultural policy, and it should stay out of that. In this way, scientific developments will take place spontaneously, depending on individual needs.

When we look at all social policy approaches, in the liberal approach; the social world is far from the government's intervention and the socialist approach has created a social world, which is without class and the power of the state can be felt. While the conservative approach aims to progress based on the traditional values, in the discourse of the social democratic approach, as in the liberal and socialist approach, a critical language is being used and seemed an approach that supports the welfare state and at the same time protects individual freedoms. The reason for a critical language is that the conservative approach is the ruling party at the same time. Therefore, in the discourses of other parties there is the criticism of the whole system. 


\section{Conclusion}

The perception of the social state and the welfare state has changed through many periods and countries. Countries that have emphasized social politics for some period have moved towards neo-liberal practices by leaving their systems at other times (For example, Turkey and New Zealand). In some countries, some progress has been made towards liberal economics and politics, instead of the social state and welfare concept (England in certain periods). On the other hand, there are countries that do not abandon their basic policy and continue to provide the welfare state to their citizens although some challenges from the globalization process (such as the Scandinavian countries). Since the existence of social politics, all these changes and formations have been shaped on the basis of individual demands and changing perceptions. But the big frame has shown that individuals regardless of their social status, have given to every struggle to create a life worthy of being human beings, after having met their most basic needs such as nutrition and shelter. If they do not reach human living conditions, civil resistance will start.

When it does not give place to the social policies, the government wants to give the following message: We, as the state, do not accept want to help everybody in need, to find jobs for everyone who has graduated from university, to provide services such as education and health for everyone who is in an inadequate financial situation as our duty and we perceive that the lack in areas such education or health, as the duty of the people concerned. This may be significant in some respects; for example, this opinion may cause the development of a more individual understanding and perspective and people working harder to leave a social class. If the individual understands that in every difficult situation he cannot run into the arms of a powerful authority like the state, he will have to "grow up", and his mind will seek to find his own solution to his problems. It will also give him the power to easily criticize and overthrow the restricted state. In such an atmosphere, the freedom of the individual and the field of personal movement will expand. It is clear that; neither the "invisible hand" nor the "spontaneous order" of the classical liberal philosophy; has been enough to raise the wealth levels of societies and to fulfil the demands of the poor. This inadequacy is a social phenomenon, as well as an economic concept, rather than an injustice in income levels. For example, in Turkey in 1980, when the state gave up producing some public services and left these services to the free market economy, the people who do not have purchasing power begin to experience deprivation. The real deprivation is to tolerate the conditions that poverty caused. The free individual cannot tolerate the poverty and social policies have been born. In addition, "wild capitalism" has been domesticated by social policies, and it no longer seems to be wild. On the other hand, it is a reality that individuals need the support of the state, and a world in which each individual attempts to solve all their problems on their own, is chaotic. For example, let us imagine a state that does not regard justice as its own task so that every individual has to create his own justice. Alternatively, let us consider the need of education for an individual who in the lowest position in the social class. The only opportunity for him or her to climb out of their social class is through education; thereby the individual can gain social status and income. The state may come face to face with social chaos created by individuals whose education is not a duty for itself.

In the 1990s, it has seemed that the centre-left parties have strengthened once again in many European countries and they have used terms such as the "Third Way" and "New Social Democracy" to distinguish themselves from previous social democratic governments and neoliberal governments (Ozdemir 2007). This new approach has focused on equality, solidarity, and 
included self-supporting parties in countries such as the United Kingdom, New Zealand, Korea, Taiwan, Brazil, and Argentina. According to Giddens, the third way is "the renewal of social democracy in a world where old left-wing ideas are now in time-out, new right-wing programs are inadequate and contradictory". In fact, social democracy was born from the search for the third way. As communism began to spread throughout the world as an alternative system, for the first time in Denmark in 1916, then in Sweden, Norway, England, and France, social democrats separated from communists, through this socialists were invited to participate in elections or multi-party coalitions. As a result, social democrats have adopted a "third-way" policy instead of communism or capitalism (Özdemir 2007).

Therefore, when all the options presented are considered, the state must have a political attitude that is fairly balanced; in some cases dominant and controlled as a socialist state; in some cases impartial, an audience, as in a liberal state. For example, in the economic field, if the level of production in the sector is low and the demand cannot be met, that sector can be encouraged by subsidies. Economic orientations are present in all developed countries that adopt liberal policies today. As another example, the state should define the freedom of the individual by staying away from certain sectors; like the press. Individuals may have the ability to express themselves freely and to preserve their right to criticize democracy.

Consequently, while the liberal approach sees the presence of the state as the main problem in the education system, the conservative view sees the system, which has inequality of opportunity, as an arena of political conflict. About basic health expenditures, the social democratic approach argues that there will be no more fees from citizens who have no financial power, under the name of contribution and, in the communist approach, because the entire health system will be in the hands of the state, health spending will not be made by the people. It is also observed that the conservative approach claims that looking after an older member of a family is a duty of their children, because of their idea concerned with protecting the family and defending its unity. The conservative view supports a woman's family life, a woman's domestic responsibilities, and motherhood, and in this way, the family is protected. According to the socialist approach, in the capitalist society, the responsibilities that burden women such as food, cleaning, childcare should be taken over by the society. In this way, the family can be reorganized based on love, by abandoning the economic and ideological role that capitalism imposes. Although a common approach has been observed in youth policies, while the conservative approach encourages youth to build a structure that is aware of their religious identity with national values; the social democratic approach requires secular and freethinking young people. While the socialist approach requires young people, who have a dream of a society that is without class and property, the liberal approach requires young people with a free and stateless understanding. While the conservative approach emphasizes domestic and national cultural values and Turkish-Islamic arts, the liberal approach opposes the existence of the state in the cultural sphere, and the socialist approach defends cultural elements must expropriate and be open to the public and not have the commodification of culture. According to the liberal approach, the state should not have a cultural and science policy. In this way, scientific developments will take place spontaneously, depending on each need.

In sum, social policies are a field that the state should have control of, and every step that is not taken in this field may result in chaotic conditions that may be followed by social explosions in the next period. However, some social policy such as excessive transfer expenditures can create a citizen who makes a political decision dependant on the social aid received. That effect can harm the process of democracy concerning the freedom of the voter. The perspective of the 
liberal approach that recognizes the freedoms associated with social life; and the perspective of the approach of socialism that is equitable, fair and demands development together; and the perspective of the approach of social democracy that government must also be subject to the rule of law, must work together for creating a people who free and happy. It is clear that we need governments that are united around a philosophy that "A man is not a believer who fills his stomach while his neighbour is hungry". This approach derives from the moral motivation at the individual level. Adopting this approach by the state results in the political and social balances of power in favour of the poor and the weak and the provision of social justice in social life. Otherwise, we are missing the fact that the right to claim human living conditions is vital, so as not to be an instrument of any political game.

\section{REFERENCES}

Alcock P., May M., Rowlingson K. (2008). Sosyal Politika: Kuramlar ve Uygulamalar. Trans. Ş. Gökbayrak. Ankara 2011.

Aysan M. F. \& Kaya A. (2008). “Türkiye’de Sosyal Politika Disiplininin ve Uygulamalarının Gelişimi”. Turkey Literature Studies Journal 6/11 (2008) 223-250.

Boratav K., Yeldan A. \& Köse A. H. (2000). Globalization, Distribution and Social Policy: Turkey, 19801998. CEPA Working Paper Series I Globalization, Labor Markets, and Social Policy a Project Funded by the John D. and Catherine T. MacArthur Foundation Working Paper No. 20 February.

Buğra A. (2007). "Poverty and Citizenship: An Overview of the Social-Policy Environment in Republican Turkey”. Int. J. Middle East Stud. (2007) 33-52. Doi: 10.1017.S0020743806391039

Ersöz H. (2011). "Doğuşundan Günümüze Sosyal Politika Anlayışı ve Sosyal Politika Kurumlarının Değişen Rolü”. Istanbul University Faculty of Economics Journal 53/2 (2011) 119-144. Retrieved from http://dergipark.gov.tr/iuifm/issue/809/8772

Oral A. İ. et al. (2012). Sosyal Politika. Eskişehir 2012 ${ }^{1}$.

Ören K. (2013). Sosyal Politika. Ankara 2013³.

Özdemir S. (2005). "Sosyal Gelişim Düzeyleri Farklı Refah Devletlerinin Sınıflandırılması Üzerine Bir İnceleme”. Journal of Social Political Conferences (2005) 231-266. Source: <http://asosindex.com/ cache/articles/sosyal-gelisim-duzeyleri-farkli-refah-devletlerinin-siniflandirilmasi-uzerine-bir-incele me-f278644.pdf>.

Özdemir S. (2007). Küreselleşme Sürecinde Refah Devleti. $2007^{2}$.

Öztekin A. (2003). Siyaset Bilimine Giriş. 2003

Şişman Y. (2017). “Türkiye’de Sosyal Politikanın Dünü, Bugünü: Hayırseverliğin Kurumsallaşması mı? Gelişim mi?”. Optimum Journal of Economics and Management Sciences 4/2 (2017) 1-22.

\section{Online Sources}

http://oxfordindex.oup.com/view/10.1093/oi/authority.20110803095705910

http://www.aile.gov.tr/

http://www.akparti.org.tr/site/akparti/parti-programi

http://www.ldp.org/parti-programi/

http://www.tkp.org.tr/tr/temel-metinler/program

https://en.wikipedia.org/wiki/Declaration_of_Philadelphia

https://www.chp.org.tr/Assets/dosya/chp-program-2015-01-12.pdf

https://www.tbmm.gov.tr/anayasa/anayasa82.htm 